\title{
Fecal excretion patterns and short term bias of internal and external markers in a digestion assay with cattle ${ }^{1}$
}

\author{
Cláudia Batista Sampaio², Edenio Detmann ${ }^{3}$, Tiago Neves Pereira Valente ${ }^{2}$, Viviane \\ Aparecida Carli Costa ${ }^{2}$, Sebastião de Campos Valadares Filho ${ }^{3}$, Augusto Cesar de Queiroz ${ }^{3}$ \\ 1 Trabalho financiado pela FAPEMIG, com apoio do CNPq e do INCT-Ciência Animal. \\ 2 Programa de Pós-Graduação em Zootecnia, Universidade Federal de Viçosa, Viçosa-MG. \\ ${ }^{3}$ Departamento de Zootecnia, Universidade Federal de Viçosa, Viçosa-MG. Pesquisador do CNPq e do INCT-Ciência Animal.
}

ABSTRACT - The objective of this work was to evaluate the fecal excretion profile and the short term bias of the external markers chromic oxide and titanium dioxide and the internal markers indigestible dry matter (iDM), indigestible neutral detergent fiber (iNDF) and indigestible acid detergent fiber (iADF) in a digestion trial with cattle fed different diets. Fourteen F1 Red Angus $\times$ Nellore bulls averaging 12 months old and $287 \mathrm{~kg}$ were kept in individual stalls. The animals were fed elephant grass silage, corn silage or signal grass hay, supplemented or not with $20 \%$ of concentrate mixture. The experiment consisted of two 13-day experimental periods according to a $2 \times 2$ Latin square design with seven squares grouping. The animals received $10 \mathrm{~g}$ of chromic oxide and $10 \mathrm{~g}$ of titanium dioxide through esophageal sounder daily. Fecal grab samples were obtained directly from the rectum of the animals at 1:30 a.m., 3:00 a.m., 4:30 a.m., 6:00 a.m., 7:30 a.m., 9:00 a.m., 10:30 a.m., 12:00 p.m., 1:30 p.m., 3:00 p.m., 4:30 p.m., 6:00 p.m., 7:30 p.m., 9:00 p.m., 10:30 p.m. and 12:00 a.m. There was no effect of forages or concentrate levels on the dimension of excretory cycle. The fundamental period of excretory cycle was 15.06 and 18.66 hours for chromic oxide and titanium dioxide, respectively and 9.93, 9.29 and 10.55 hours for iDM, iNDF and iADF, respectively. The oscillation range was higher for external markers. Considering the characteristics of all evaluated markers together, it is recommended fecal sampling designs with at least four collections, distributed during the day or only in the diurnal period for obtaining fecal excretion estimates free of short term bias.

Key Words: chromic oxide, indigestible acid detergent fiber, indigestible dry matter, indigestible neutral detergent fiber, titanium dioxide

\section{Perfis de excreção fecal e vício de tempo curto de indicadores internos e externos em ensaio de digestão com bovinos}

\begin{abstract}
RESUMO - Objetivou-se avaliar o perfil de excreção fecal e o vício de tempo curto dos indicadores externos óxido crômico e dióxido de titânio e dos indicadores internos matéria seca indigestível (MSi), fibra em detergente neutro indigestível (FDNi) e fibra em detergente ácido indigestível (FDAi) em ensaio de digestão com bovinos alimentados com diferentes dietas. Foram utilizados 14 novilhos F1 Red Angus × Nelore, não-castrados, com idade e peso médios de 12 meses e $287 \mathrm{~kg}$, mantidos em baias individuais. Os animais foram alimentados com silagem de capim-elefante, silagem de milho ou feno de capim-braquiária, suplementados ou não com $20 \%$ de mistura concentrada. O experimento foi constituído de dois períodos de 13 dias, segundo delineamento em quadrado latino $2 \times 2$, com agrupamento de sete quadrados. Os animais receberam diariamente $10 \mathrm{~g}$ de óxido crômico e 10 g de dióxido de titânio por meio de sonda esofágica. Foram realizadas coletas fecais pontuais (grab samples), diretamente do reto dos animais, nos horários de 1h30, 3h00, 4h30, 6h00, 7h30, 9h00, 10h30, 12h00, 13h30, 15h00, 16h30, 18h00, 19h30, 21h00, 22h30 e 24h00. Não foram observados efeitos das forragens ou dos níveis de concentrado sobre a dimensão do ciclo excretório. O período fundamental do ciclo excretório foi de 15,06 e 18,66 horas para o óxido crômico e dióxido de titânio, e de 9,93; 9,29 e 10,55 horas para MSi, FDNi e FDAi respectivamente. Verificou-se maior amplitude de oscilação para os indicadores externos. Considerando-se conjuntamente as características dos indicadores avaliados, recomendam-se delineamentos de amostragem fecal com o mínimo de quatro coletas, distribuídas ao longo do dia ou somente no período diurno, para obtenção de estimativas de excreção fecal isentas de vício de tempo curto.
\end{abstract}

Palavras-chave: dióxido de titânio, fibra em detergente ácido indigestível, fibra em detergente neutro indigestível, matéria seca indigestível, óxido crômico 


\section{Introduction}

Estimation of diet digestibility is based on the apparent indigestibility as starting point. In this context, fecal excretion is the basic parameter of indigestibility of a food or diet, because it represents, as least apparently, the portion of ingested food which was not used during passage through gastrointestinal tract (Detmann et al., 2004).

However, as total collection of feces is hard to be done, indirect methods for fecal mass estimation, such as use of markers, are usually demanded in cattle assays.

The chromic oxide $\left(\mathrm{Cr}_{2} \mathrm{O}_{3}\right)$ is the most used external marker in cattle assays. Currently, some legal aspects regarding chromic oxide utilization has been highlighted due to its possible carcinogenic properties (Myers et al., 2006), being not approved for animal or human feeding by Food and Drug Administration (Titgmeyer et al., 2001).

The titanium dioxide $\left(\mathrm{TiO}_{2}\right)$ has been suggested as an alternative to oxide chromic in ruminant assays (Titgemeyer et al., 2001; Myers et al., 2006; Glindemann et al., 2009; Sampaio et al., 2011). This compound is usually present in some products for human feeding and has no limitation concerning its inclusion in animal food (Sampaio et al., 2011).

With regard to internal markers, the indigestible residues are most used in digestion trails with ruminants, being commonly represented by indigestible dry matter (iDM), indigestible neutral detergent fiber (iNDF) and indigestible acid detergent fiber (iADF) (Detmann et al., 2004). The basic assumption for using internal markers is supported by the fact that as feed passes through gastrointestinal tract, the content of markers increases gradually by removal of other digestible components for digestion and absorption.

The estimation of fecal marker content is frequently done by analyses of grab samples obtained from the rectum at one or two fixed sampling times a day (Detmann et al., 2001; Ítavo et al., 2002). However, it should be taken into account that probability of bias occurrence could be significant.

The total bias of an estimate of fecal excretion obtained by using markers can be divided in two different components: long term bias and short term bias (Langlands et al., 1963).

The long term bias, also called recovering bias, is associated with the capacity of a marker to be totally recovered in feces (Langlands et al., 1963, Detmann et al., 2007a). This is supposed to be an inherent characteristic of the marker. Thereby, any marker can be surely used in digestion trials only if it is assumed to be free of long term bias (Detmann et al., 2007a). On the other hand, the short term bias corresponds to the portion of total bias of an estimate of fecal excretion which is associated with fails or inconsistencies in the procedures for obtaining fecal samples that are representative of the total excreted feces (Langlands et al., 1963). Its elimination depends directly on fecal sampling design.

Some Brazilian reports have pointed out reliable estimates of total recovering bias of internal and external markers (Berchielli et al., 2000; Zeoula et al., 2002; Cabral et al., 2008). However, such evaluation could not contribute for identifying marker constraints concerning to fecal recovering or fail in fecal sampling.

By considering this, there is not enough information that supports the use of efficient fecal sampling designs, which could minimize occurrence of short term bias. Such knowledge is still restricted to few works where only chromic oxide was used as external marker (Smith \& Reid, 1955; Brisson etal., 1957; Hopper etal., 1978; Priggeetal., 1981).

So, the objective of this work was to evaluate the daily excretion pattern and short term bias considering different fecal sampling designs of chromic oxide, titanium dioxide, iDM, iNDF and iADF in cattle fed different diets.

\section{Material and Methods}

The experiment was carried out in the Animal and Animal Nutrition Laboratories of Departamento de Zootecnia at the Universidade Federal de Viçosa, Viçosa, MG.

Fourteen F1 Red Angus $\times$ Nelore bulls averaging 12 months old and $287 \pm 36 \mathrm{~kg}$ were kept in individual stalls. Elephant grass (Pennisetum purpureum) silage (six animals), corn (Zea mays) silage (six animals) and signal grass (Brachiaria decumbens) hay (two animals) were used as forage. The experiment consisted of two 13-days experimental periods, and the first five days were allocated to the adaptation of the animals to the diets followed by eight days of sample collection. The animals were adapted to experimental conditions during 14 days prior the experimental periods.

In the first period, half of the animals in each forage received a concentrate supplemented, which was supplied at $20 \%$ of the total diet as dry matter (DM) basis. In the second experimental period the concentrate supplementation was crossed over to the animals not supplemented in the first period. The concentrate was based on corn grain, soybean meal and mineral mixture and presented approximately $30 \%$ of crude protein (CP), as DM basis.

The feed samples were analyzed for contents of DM, organic matter, and acid detergent fiber according to 
Silva \& Queiroz (2002). The ether extract contents were obtained by petroleum ether extraction using a XT15 extractor (Ankom $\left.{ }^{\circledR}\right)$. The neutral detergent fiber (NDF) was evaluated according to Mertens (2002), using a heat-stable alpha amylase, without using sodium sulphite. The corrections of NDF concerning ash and protein were done by using methods of Mertens (2002) and Licitra et al. (1996), respectively (Table 1 ).

During all experimental period, chromic oxide (10 g) and titanium dioxide ( $10 \mathrm{~g}$ ) were daily supplied to the animals at 12 p.m. by using an esophageal sounder.

Total collection of feces was performed on the first, fourth and seventh days of the collection period, beginning at 7 a.m. and keeping over 24 hours. The feces were collected after spontaneous defecation and packed in polyethylene containers. After that, the feces were homogenized and weighed. Representative samples (approximately $10 \%$ of the total feces) were taken and frozen $\left(-20^{\circ} \mathrm{C}\right)$.

Fecal grab samples were obtained at 1:30 a.m., 3:00 a.m., 4:30 a.m., 6:00 a.m., 7:30 a.m., 9:00 a.m., 10:30 , 12:00 p.m., 1:30 p.m., 3:00 p.m., 4:30 p.m., 6:00 p.m., 7:30 p.m., 9:00 p.m., 10:30 p.m. and 12:00 a.m. on the second, fifth and eighth days of collection period. The samples were taken from the rectum of animals and frozen at $-20^{\circ} \mathrm{C}$.

For the quantification of voluntary intake, feedstuffs supplied between the sixth and the twelfth days of each experimental period were considered and the orts were measured from the seventh to the thirteenth day. Composite samples were elaborated per animal and experimental period and frozen at $-20^{\circ} \mathrm{C}$.

Feces, feed and ort samples were thawed at environment temperature, oven-dried $\left(60^{\circ} \mathrm{C}\right)$ and processed in a knife mill (2 mm). After that, representative fecal samples obtained through total collection were composed by animal and experimental period. All samples were analyzed for dry matter content (Silva \& Queiroz, 2002).

Representative and grab samples of feces were evaluated for chromium and titanium dioxide contents by using atomic absorption (Williams et al., 1962) and colorimetric (Myers et al., 2004) methods, respectively.

For quantification of internal markers contents, three aliquots of each feed, ort and feces sample were put in nonwoven textile bags $\left(100 \mathrm{~g} / \mathrm{m}^{2} ; 4 \times 5 \mathrm{~cm}\right)$, at a ratio of $25 \mathrm{mg}$ $\mathrm{DM} / \mathrm{cm}^{2}$ of surface. The bags were then heat-sealed.

The bags were kept for 264 hours (Casali et al., 2008) in the rumen of a bull fed a corn silage:concentrate diet (80:20). After that, the bags were cleaned with tap water, sequentially oven dried at $60^{\circ} \mathrm{C}$ ( 72 hours) and $105^{\circ} \mathrm{C}$ ( 1 hour), kept in a dissecator and weighed. The residue was supposed to be iDM. The weighing procedure was done by limiting to 20 the number of bags put in the dissecator. Such restriction was adopted to avoid constraints concerning to moisture absorption by the residue.

The bags were then submitted to extraction with neutral detergent (Mertens, 2002) by using a fiber analyzer (Ankom ${ }^{200} ;{ }^{\circledR} 100^{\circ} \mathrm{C} / 1$ hour). After the extraction, the bags were washed with hot water and acetone, and dried and weighed as described above. The residue was assumed as iNDF. Acid detergent extraction was sequentially done to obtain the iADF contents. It was used the acid detergent composition described by Goering \& Van Soest (1975).

For the evaluation of daily excretion pattern, the fecal contents of markers in grab samples were submitted to the adjustment of a trigonometric polynomial according to a Fourier's series as a function of sampling time (Detmann et al., 2007b). The general model can be described as:

$$
Y_{t}=A_{0}+\sum_{k=1}^{K}\left[A_{k} \times \sin (k \times c \times t)+B_{k} \times \cos (k \times c \times t)\right]
$$

where: $\mathrm{Y}_{\mathrm{t}}=$ the estimated marker content in feces at sampling timetable " $\mathrm{t}$ " $\%$ of DM), $\mathrm{A}_{0}=$ the mean marker concentration in feces (\% of DM), $A_{k}$ and $B_{k}=$ parameters without biological meaning, $\mathrm{c}=$ the fundamental dimension of excretory cycle ( $\mathrm{rad} / \mathrm{h}), \mathrm{k}=$ the indexer of Fourier's series, being integer and positive and varying from 1 to $\mathrm{K}$, and $\mathrm{t}=$ the sampling timetable.

Table 1 - Chemical composition of feeds

\begin{tabular}{|c|c|c|c|c|}
\hline & \multicolumn{4}{|c|}{ Feed } \\
\hline Dry matter (\%) & 28.4 & 31.2 & 92.8 & 88.1 \\
\hline Crude protein (\% of dry matter) & 6.1 & 4.4 & 4.4 & 29.5 \\
\hline Ether extract (\% of dry matter) & 3.6 & 1.5 & 1.3 & 1.1 \\
\hline $\begin{array}{l}\text { Neutral detergent fiber corrected for ash } \\
\text { and protein (\% of dry matter) }\end{array}$ & 49.9 & 71.9 & 79.2 & 7.9 \\
\hline Non-fibrous carbohydrates ( $\%$ of dry matter $)^{1}$ & 36.2 & 14.7 & 10.9 & 56.4 \\
\hline
\end{tabular}

${ }^{1} \mathrm{NFC}=\mathrm{OM}-(\mathrm{CP}+\mathrm{EE}+\mathrm{NDFap})$. 
It is anticipated that all adjustments were found adequate using $\mathrm{k}=2$. From this, equation (1) can be described as:

$Y_{t}=A_{0}+A_{1} \times \sin (c \times t)+B_{1} \times \cos (c \times t)+A_{2} \times \sin (2 \times$

$\times c \times t)+B_{2} \times \cos (2 \times c \times t)$

Considering $\mathrm{k}=2$, the fundamental period of excretion cycle was estimated according the equation (Detmann et al., 2007b):

$P=\frac{2 \pi}{k c}=\frac{\pi}{c}$

in which $\mathrm{P}$ = the fundamental period of excretory cycle $(\mathrm{h})$.

For the adjustments of non-linear model described in equation (2), it was used the iterative algorithm of GaussNewton implemented in PROC NLIN of SAS. The comparison among different feeding conditions (forages and concentrate levels) was performed by using the $\chi^{2}$ distribution according the identity test for non-linear models suggested by Regazzi (2003). This test was independently applied for each marker $(n=1344)$ based on two hypotheses: difference among forages and difference between concentrate levels.

It must be anticipated that statistical evaluation described above was performed just on parameter "c" because this one represents the influence of feeding conditions on excretory dynamics of markers. The parameters $A_{k}$ and $B_{k}$ were not evaluated because of their lack of biological meaning (Equation 1). On the other hand, the average fecal contents of markers $\left(\mathrm{A}_{0}\right)$ were not compared because they are dependent on the diet content and differences among feeding conditions would be expected.

The fecal excretion estimates based on representative fecal samples were obtained as:

$F E_{R S}=\frac{D}{[M]_{R S}}$

in which $\mathrm{FE}_{\mathrm{RS}}=$ the fecal excretion estimated by using the marker content in the fecal representative sample $(\mathrm{g} / \mathrm{d})$,
$\mathrm{D}=$ the daily dose of external marker or the daily intake of internal marker $(\mathrm{g} / \mathrm{d})$, and $[\mathrm{M}]_{\mathrm{RS}}=$ the marker content in the representative fecal sample ( $\mathrm{g} / \mathrm{g})$.

Different fecal sampling designs were produced from combinations of marker contents in different sampling timetables (Table 2). Therefore the estimates of fecal excretion obtained by grab samples in each design were obtained as:

$$
F E_{G S}=\frac{D}{[M]_{G S}}
$$

in which: $\mathrm{FE}_{\mathrm{GS}}$ = the fecal excretion estimated by using marker content in fecal grab samples according to the fecal sampling design (g/d), D = the daily dose of external marker or the daily intake of internal marker $(\mathrm{g} / \mathrm{d})$, and $[\mathrm{M}]_{\mathrm{GS}}=$ the marker content in fecal grab samples according to the fecal sampling design (g/g).

The experiment was carried out according to a $2 \times 2$ latin square design (Cochran \& Cox, 1957), with two experimental periods and seven replicates of squares (three with corn silage, three with elephant grass silage, and one with signal grass hay). The concentrate levels in the diet (0 or 20\%) were evaluated within each square, being crossed over the experimental periods. Therefore, a $3 \times 2$ factorial arrangement was adopted ( 3 forages and 2 concentrate levels), according to the model:

$Y_{i j k l}=\mu+F_{i}+N_{j}+F N_{i j}+P_{k}+A_{(i) l}+\varepsilon_{i j k l}$

where $Y_{i j k l}=$ fecal excretion estimated in the animal l, during period $\mathrm{k}$, fed the forage $\mathrm{i}$ and the concentrate level $\mathrm{j} ; \mu=$ the general constant; $F_{i}=$ effect of forage (fixed); $N_{j}=$ the effect of concentrate level $\mathrm{j}$ (fixed); $\mathrm{FN}_{\mathrm{ij}}=$ the interaction of forage $\mathrm{i}$ and concentrate level $\mathrm{j}$ (fixed); $\mathrm{P}_{\mathrm{k}}=$ the effect of the experimental period $\mathrm{k}$ (fixed); $\mathrm{A}_{(\mathrm{i}) \mathrm{l}}=$ the effect of animal $\mathrm{k}$ nested to forage i (random); and $\varepsilon_{\mathrm{ijkl}}=$ the experimental error supposed to be normal and independently distributed with mean zero and variance $\sigma^{2}$.

Table 2 - Fecal sampling designs produced from combination of grab samples taken at different timetables

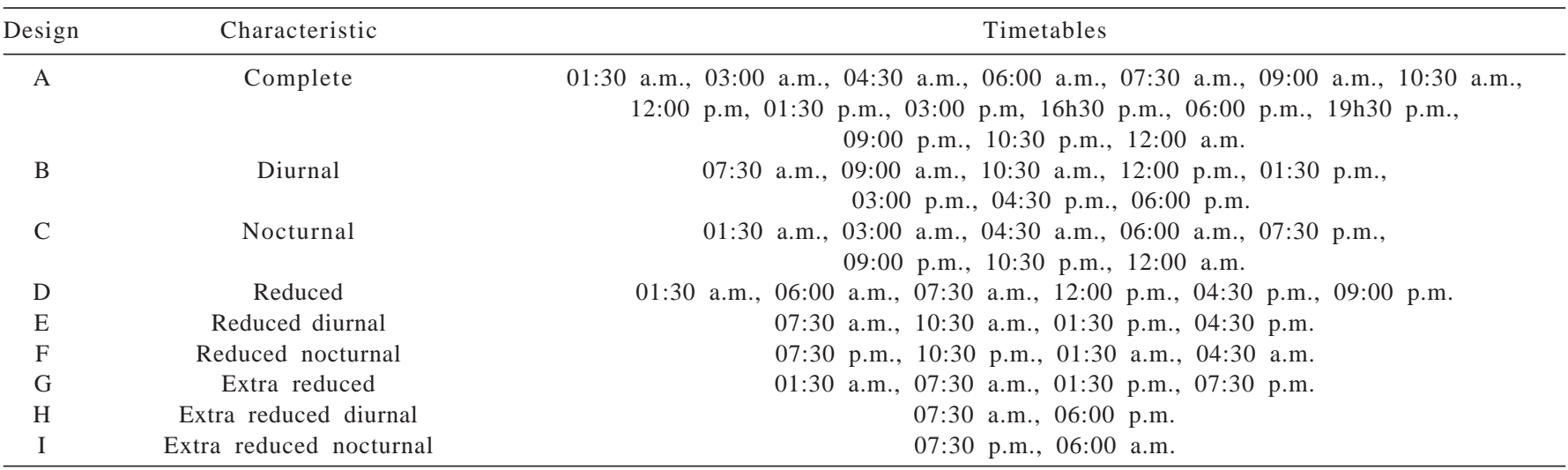


The occurrence of short term bias on fecal excretion was evaluated by using a split-plot arrangement according to estimates obtained from representative fecal samples or different sampling designs (Table 2). The estimate of fecal excretion obtained using a fecal sampling design was supposed to be free of short term bias if no difference was observed when compared to estimate obtained with representative fecal sample. It was used the Dunnett's test $(\alpha=0.05)$. These evaluations were independently performed for each marker (Equation 6) by using the PROC GLM of SAS. Type III sums of squares were used (Littell et al., 1991) due to imbalance of observations in different forages.

\section{Results and Discussion}

The statistical results concerning fecal excretion of dry matter were found similar for all evaluated markers. Such statement is based on descriptive levels of probability for type I error, which were found very similar among markers (Table 3). Accordingly, considering that intake is directly measured by weighing the offered feeds and orts, the similar statistical inferences concerning fecal excretion will lead to similar inferences concerning digestibility coefficients for any marker. Such result indicates that choice of marker can be based on secondary characteristics, such as analytical methods, markers cost, etc.

There were no effects $(\mathrm{P}>0.05)$ of forage or concentrate level on the fundamental dimension of excretory cycle (c) (Table 4). This indicates that pattern of marker transit through gastrointestinal tract was independent of forage and concentrate level. By considering each marker, such behavior presents direct experimental implications because there would not be a possibility of occurrence of confounded effects regarding differential flow of marker caused by different diets in an experiment. Thereby, the same fecal sampling design could be used for any diet and adjustments regarding differential flow among diets are not necessary. This statement corroborates one of the demanded characteristics for an ideal marker, which one establishes that marker flow should not be affected by diet (Owens \& Hanson, 1992).

Assuming that diets do not influence estimates of parameter "c", a single model was adjusted for each marker to describe the other excretory characteristics (Table 4; Figures 1 and 2).

For the external markers, the fundamental periods of excretory cycle were 15.06 hours for chromium and 18.66 hours for titanium dioxide. Additionally, iDM, iNDF and

Table 3 - Descriptive levels of probability for type I error associated with main effects and their interaction for fecal excretion using different markers

\begin{tabular}{lrcr}
\hline Marker & & Effect $^{1}$ & \\
\cline { 2 - 4 } & Forage & Concentrate level & Forage $\times$ concentrate level \\
\hline $\mathrm{Cr}_{2} \mathrm{O}_{3}$ & 0.0001 & 0.0099 & 0.4935 \\
$\mathrm{TiO}_{2}$ & $<0.0001$ & $<0.0001$ & 0.4398 \\
$\mathrm{iDM}$ & 0.0002 & 0.0012 & 0.6398 \\
$\mathrm{iNDF}$ & 0.0001 & 0.0010 & 0.3794 \\
$\mathrm{iADF}$ & 0.0001 & 0.0011 & 0.4827 \\
\hline
\end{tabular}

${ }^{1}$ It was used information from all fecal sampling designs to evaluate the descriptive levels of probability.

Table 4 - Descriptive levels of asymptotic probability for type I error associated with evaluation of forage and concentrate level effects on the fundamental dimension of excretory cycle (c) and parameters of fecal excretion pattern of different markers

\begin{tabular}{|c|c|c|c|c|c|}
\hline \multirow[b]{2}{*}{ Item } & \multicolumn{5}{|c|}{ Marker } \\
\hline & $\mathrm{Cr} 2 \mathrm{O} 3$ & $\mathrm{TiO} 2$ & iDM & iNDF & iADF \\
\hline \multicolumn{6}{|l|}{$\mathrm{P}$ value } \\
\hline Concentrate & 0.3214 & 0.7344 & 0.8907 & $>0.9999$ & 0.9028 \\
\hline \multicolumn{6}{|l|}{ Parameter } \\
\hline c (rad/h) & 0.2086 & 0.1684 & 0.3163 & 0.3383 & 0.2979 \\
\hline $\operatorname{Cmin}(\%)^{2}$ & 0.28 & 0.54 & 64.54 & 53.25 & 35.01 \\
\hline$A_{0}(\%)^{2}$ & 0.32 & 0.59 & 66.28 & 54.54 & 36.38 \\
\hline OR $(\%)^{3}$ & 23.96 & 21.22 & 6.56 & 5.76 & 8.52 \\
\hline
\end{tabular}

${ }^{1}$ Fundamental period $(\mathrm{FP}=\pi / \mathrm{c})$.

${ }^{2} \mathrm{Cmax}, \mathrm{Cmin}$ and $\mathrm{A}_{0}=$ estimates of maximum, minimum and average marker content in feces.

${ }^{3}$ Estimated oscillation range $\left[\mathrm{OR}=(\mathrm{Cmax}-\mathrm{Cmin}) / \mathrm{A}_{0}\right]$. 


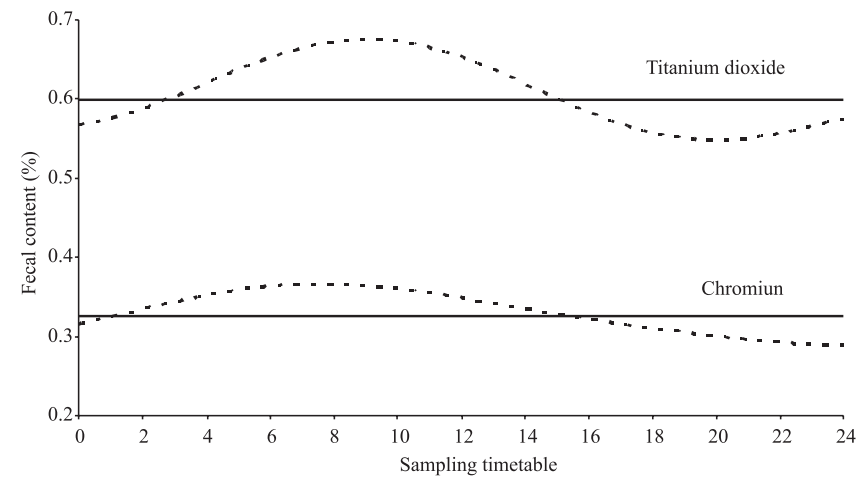

Figure 1 - Estimated fecal concentration of chromium and titanium dioxide according to sampling timetables (dashed line $=$ adjusted function; continuous line $=$ estimated mean concentration).

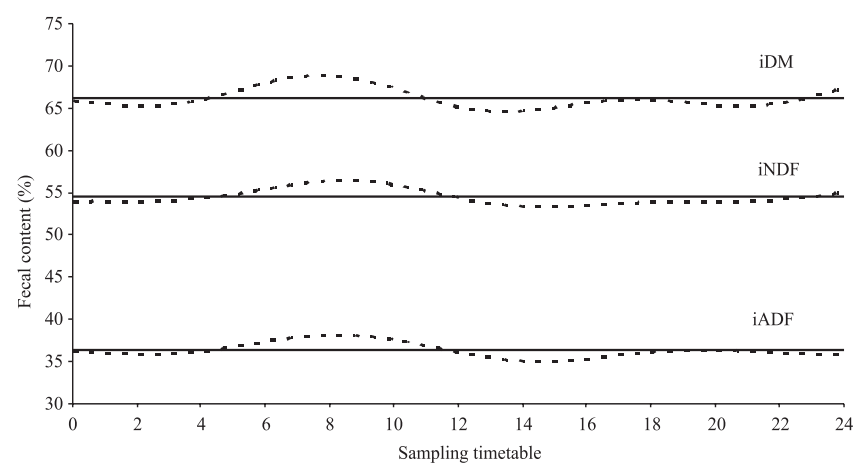

Figure 2 - Estimated fecal concentration of iDM, iNDF and iADF according to sampling timetables (dashed line = adjusted function; continuous line = estimated mean concentration).

iADF presented fundamental period of 9.93, 9.29 and 10.55 hours, respectively.

The chromic oxide is the most studied marker regarding to the pattern of fecal excretion. It has been assumed that its daily excretion curve presents a symmetrical pattern with a maximal and a minimal concentration and total period for cycling close to 24 hours (Smith \& Reid, 1955; Hopper et al., 1978). It implicates that estimate of parameter "c" would be approximately $0.13 \mathrm{rad} /$ hour (Hopper et al., 1978).

However, those assumptions have not been supported in several studies. Fundamental periods close to 3, 4 and 12 hours were founded by Barros et al. (2007), Dias (2009) and Linnerud \& Donker (1961), respectively.

The fundamental periods obtained in this study for all markers were not exact or approximate natural dividing of 24 hours (Table 4). Thereby, considering that mathematical domain of adjusted models was a 24 hours period, the multiplication of estimated fundamental periods by natural numbers will not produce or will extrapolate 24 hours. Therefore, the estimates of parameter "c" must be seen as scalar parameters for describing excretion pattern, which can generate useful information to understand how optimal fecal sampling design can be defined.

The oscillation range of a marker informs the maximum variability of its fecal contents around mean fecal concentration. The estimates founded for the external markers (23.96 and 21.22\% for chromic oxide and titanium dioxide, respectively) were higher than ones obtained for internal markers (6.65, 5.76 and 8.52\% for iDM, iNDF and iADF, respectively). This pattern is showed in Figures 1 and 2 where it can be noted that internal markers presented estimated fecal contents closer to the average fecal concentration compared to external markers.

Barros et al. (2007) evaluated the daily excretion pattern of several markers in cattle and also observed that fecal contents of internal markers (iNDF and iADF) were closer to the average concentration when compared to chromic oxide. Those authors verified that oscillation range of internal markers were close to $5 \%$, similar to the one obtained in this work.

One of the characteristics of an ideal marker is defined by its capacity to flow parallel or to be physically similar or to be closely associated with evaluated feed, feed constituent or diet (Owens \& Hanson, 1992). Once internal markers are natural compounds of the feeds, it can be expected that their flow through gastrointestinal tract be similar to digesta flow (Sampaio et al., 2011). Such argument seems to support the lower oscillation of fecal content of internal markers (Table 4; Figure 2).

On the other hand, several constraints concerning to differences between diet and external markers flows have been reported, noticeably for chromic oxide, which involves incomplete mixing with ruminal contents (Corbett et al., 1959) and faster flow compared to fibrous material (Van Soest, 1994). From this, the peculiarities of external markers flow seem to be associated with their higher variability regarding fecal contents when compared to internal markers (Table 4; Figure 1).

However, it should be emphasized that lower fecal contents of external markers could lead to high relative variations around average concentration despite of the low absolute variation. It will implicatein higher oscillation range compared to internal markers, which present higher fecal contents. The absolute differences between maximal and minimal contents are relatively low for external markers (Table 4) that produced a pattern of fecal concentration very near to steady state (Figure 1). Thus, the oscillation range could be seen as a relative characteristic rather than 
an absolute criterion to define the recommendation or not of markers evaluated in this study.

For all evaluated markers, it was observed increase of fecal contents above average concentration in the morning. Additionally, the fecal contents of external markers decreased below average contents during vespertine and nocturnal periods. Similar patterns were reported for chromic oxide by Smith \& Reid (1955), Brisson et al., (1957) and Hooper (1978); and for titanium dioxide by Myers et al. (2006) and Glindemann et al. (2009). On the other hand, the internal markers, even presented decrease in contents during vespertine period, kept fecal contents close to average concentration in the nocturnal period (Figures 1 and 2).

This pattern, noticeably for internal markers, seems to be associated with natural events of transit and degradation dynamics. The outflow of indigestible residues from rumen (which encompass the internal markers evaluated in this study) occur only by the passage. However, rate of passage is closely associated with degradation of digestible fraction (Detmann, 2010). Despite of degradation and transit being continuous in the rumen, the input of new material to be degraded and removed increases during feeding periods. Thereby, higher mass will be submitted to degradation during specific timetables, which can cause inconstancy in fecal contents, it was verified in this study.

There is no direct influence of degradation process on external markers; however they are subjected to the transit events in the rumen. Thus, these compounds should present transit similar to digesta which would cause similar pattern to internal markers, as it was verified in this study (Figures 1 e 2).

The difference between the estimate of fecal excretion obtained by marker content in fecal grab samples and the real value of fecal excretion is assumed to be the total bias of the estimate (Langlands et al., 1963). This bias can be divided in two portions. The first one is called long term bias or recovering bias and corresponds to the capacity of a marker to be excreted in quantity equal to its intake (Langlands et al., 1963; Detmann et al., 2007a). This characteristic must be assumed as inherent to the marker (Sampaio et al., 2011). The second portion is called short term bias and corresponds to the bias of estimate caused by lack of representativeness of fecal grab samples (Langlands et al., 1963).

Is must be emphasized that all markers were found free of long term bias (Sampaio et al., 2011); in other words, they present complete fecal recovering. So, they can be surely used in digestion assays with ruminant animals because any constraint with regard to total bias could be outlined by adapting fecal sampling procedure, which is responsible for the short term bias (Detmann et al., 2007a).

For the chromic oxide, it was observed occurence of short term bias $(\mathrm{P}<0.05)$ when $\mathrm{C}$, F and I sampling designs (Table 2 ) were used. These designs were based on nocturnal fecal samples (Table 5). In this case, it was verified that fecal excretion was overestimated $(\mathrm{P}<0.05)$, which reflects the decreased fecal contents observed at night (Figure 1). According to results presented in Table 5, the increase in marker content in the morning (Figure 1) did not cause a significant loss of representativeness of grab samples and no short term bias was observed when diurnal samples were used.

There was no short term bias for any fecal sampling design when titanium dioxide was evaluated ( $\mathrm{P}>0.05$; Table 5 ) even considering its variation during the day (Figure 1). Such pattern corroborates that replacing chromic oxide by titanium dioxide can produce similar or more accurate estimates of fecal excretion.

Among internal markers, the iDM presented the highest number of fecal sampling designs with significant short

Table 5 - Estimates of fecal excretion (g/d) obtained by using representative fecal sample or by different fecal sampling designs according to the markers

\begin{tabular}{|c|c|c|c|c|c|}
\hline \multirow[b]{2}{*}{ Design $^{2}$} & \multicolumn{5}{|c|}{ Marker } \\
\hline & $\mathrm{Cr}_{2} \mathrm{O}_{3}$ & $\mathrm{TiO}_{2}$ & iDM & iNDF & iADF \\
\hline Representative sample & 1849.1 & 1773.5 & 1808.1 & 1853.1 & 1760.0 \\
\hline B & 1990.7 & 1696.3 & 1785.3 & 1813.1 & 1719.0 \\
\hline $\mathrm{C}$ & $2114.9 *$ & 1800.1 & 1784.4 & 1833.0 & 1744.3 \\
\hline $\mathrm{D}$ & 1979.1 & 1770.0 & 1771.0 & 1826.6 & 1715.5 \\
\hline G & 1913.2 & 1733.9 & $1746.5 *$ & 1815.1 & 1725.8 \\
\hline $\mathrm{H}$ & 1928.1 & 1781.7 & $1726.1 *$ & $1803.0 *$ & $1697.7^{*}$ \\
\hline I & $2114.1 *$ & 1765.5 & $1752.0 *$ & 1819.5 & $1709.1^{*}$ \\
\hline CV (\%) & 10.8 & 7.5 & 3.3 & 3.2 & 3.8 \\
\hline
\end{tabular}

${ }_{1}^{1}$ Means in the column followed by * are different form means obtained by using representative sample by Dunnett's test (P<0.05).

2 See details of fecal sampling designs in Table 2. 
term bias $(\mathrm{P}<0.05)$. However, there is not a specific behavior to explain why such biases were detected on those designs (Table 5). Some authors have pointed out that iDM could be fairly used as internal marker (Huhtanen et al., 1994; Detmann et al., 2001). However, the presence of contaminants may compromise the results (Huhtanen et al., 1994; Casali et al., 2009) because detergents are not used to clean the residues after incubation and the withdrawal of microbial debris and particles through anionic action become limited (Valente et al., 2011). The contaminant residues would overestimate fecal content of iDM and underestimate the fecal excretion, such as verified when short term bias was significant when iDM was used (Table 5).

The level of contamination by residues seems to be not constant among materials (Sampaio et al., 2011). Such characteristic increases the variability of results, reduces the accuracy of fecal recovering of iDM and indicates that iDM should not be used as internal marker in ruminant digestion trials, as reported by several authors (Casali et al., 2009; Sampaio et al., 2011; Valente et al., 2011).

When using iNDF and iADF, the most fecal sampling designs were found to be free of short term bias $(\mathrm{P}>0.05)$. Significant biases $(\mathrm{P}<0.05)$ were observed when only two points of daily profile were considered (Table 5).
In several nutrition experiments it is necessary to use more than one marker simultaneously. Thereby, it is a relevant aim to propose a standard fecal sampling design that allows using two or more of the markers evaluated in this study (except for iDM, as discussed before). Simultaneous utilizations of markers were verified when the voluntary intake of grazing animals or group fed animals is measured. In this context and by considering the results of this work, it must be recommended that at least four points of fecal collections should be considered. The suggested number of grab samples is based on limitations observed for iNDF and iADF when less than four sampling points were used (Table 5). The collection points must be distributed over the day or only over diurnal period. The fecal sampling design can not be based on nocturnal collections because there are limitations for chromic oxide utilization (Table 5).

Despite of accuracy of results, there are few variations regarding to precision of fecal excretion estimates by using different fecal sampling designs (Table 6). Such pattern indicates that evaluating a marker only through precision aspects can lead to erroneous inferences because some estimates can be precise but not accurate and estimates of digestibility coefficients could be biased.

Table 6 - Indexes of variation of fecal excretion estimates obtained by using representative fecal sample or by different fecal sampling designs according to the markers

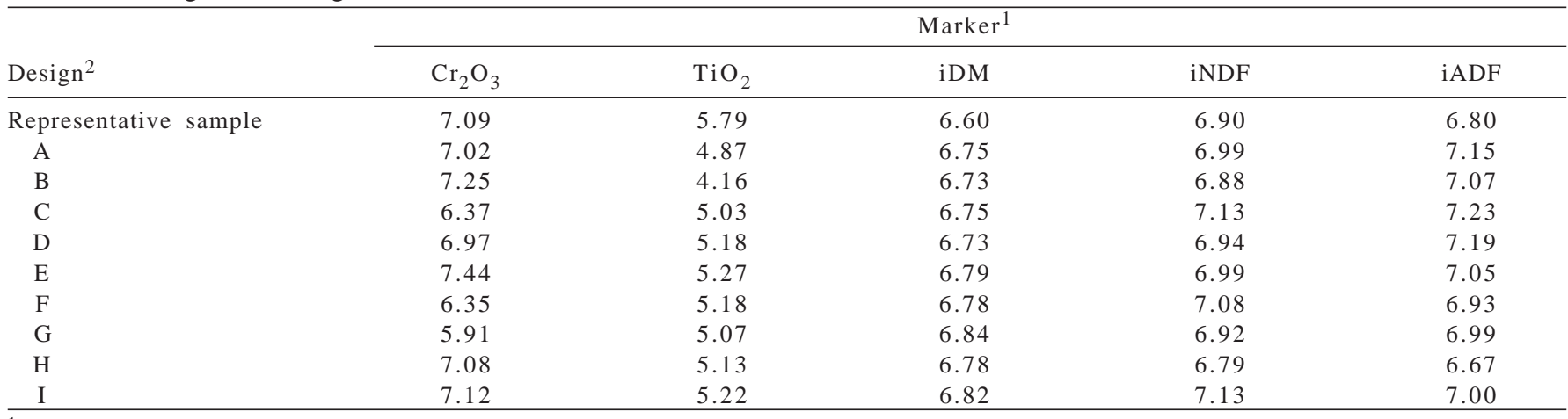

Index of variation $=($ standard error $/$ mean $) \times 100$.

${ }^{2}$ See details of fecal sampling designs in Table 2.

\section{Conclusions}

By considering the characteristics of chromic oxide, titanium dioxide, indigestible neutral detergent fiber and indigestible acid detergent fiber simultaneously, it is suggested to use fecal sampling designs based on at least four collection points for representing the daily excretion profile, which can be distributed along all day or only during diurnal period.

\section{Acknowledgments}

The authors would like to thank Professor Dilermando Miranda da Fonseca (DZO-UFV), who kindly supplied the animals for the experiment.

\section{References}

BARROS, E.E.L.; FONTES, C.A.A.; DETMANN, E. et al. Avaliação do perfil nictemeral de excreção de indicadores internos e de 
óxido crômico em ensaios de digestão com ruminantes. Revista Brasileira de Zootecnia, v.36, p.2102-2108, 2007.

BERCHIELLI, T.T.; ANDRADE, P.; FURLAN, C.L. Avaliação de indicadores internos em ensaios de digestibilidade. Revista Brasileira de Zootecnia, v.29, n.3, p.830-833, 2000.

BRISSON, G.J.; PIGDES, W.J.; SYLVESTRE, P.E. Effect of frequency of administration of chromic oxide on its fecal excretion pattern by grazing cattle. Canadian Journal of Animal Science, v.37, n.1, p.90-94, 1957

CABRAL, L.S.; VALADARES FILHO, S.C.; DETMANN, E. et al. Avaliação de indicadores na estimação da excreção fecal e da digestibilidade em ruminantes. Revista Brasileira de Saúde e Produção Animal, v.9, p.29-34, 2008.

CASALI, A.O.; DETMANN, E.; VALADARES FILHO, S.C. et al. Influência do tempo de incubação e do tamanho de partículas sobre os teores de compostos indigestíveis em alimentos e fezes bovinas obtidos por procedimentos in situ. Revista Brasileira de Zootecnia, v.37, p.335-342, 2008.

CASALI, A.O.; DETMANN, E.; VALADARES FILHO, S.C. et al. Estimação de teores de componentes fibrosos em alimentos para ruminantes em sacos de diferentes tecidos. Revista Brasileira de Zootecnia v.38, p.130-138, 2009.

COCHRAN, W.G.; COX, G.M. Experimental designs. 2.ed. New York: John Willey \& Sons, 1957. 611p.

CORBETT, J.L.; GREENHALGH, J.F.D.; FLORENCE, E. Distribution of chromium sesquioxide and polyethyleneglycol in the reticulum-rumen of cattle. British Journal of Nutrition, v.13, p.337-345, 1959.

DETMANN, E. Fibra na nutrição de novilhas leiteiras. In: PEREIRA, E.S.; PIMENTEL, P.G.; QUEIROZ, A.C. et al. (Eds.) Novilhas leiteiras. Fortaleza: Graphiti, 2010. p.253-302.

DETMANN, E.; PAULINO, M.F.; ZERVOUDAKIS, J.T. et al. Cromo e indicadores internos na determinação do consumo de novilhos mestiços, suplementados, a pasto. Revista Brasileira de Zootecnia, v.30, p.1600-1609, 2001.

DETMANN, E.; VALADARES FILHO, S.C.; PAULINO, M.F. et al. Avaliação da técnica dos indicadores na estimação do consumo por ruminantes em pastejo. Cadernos Técnicos de Veterinária e Zootecnia, v.46, p.40-57, 2004.

DETMANN, E.; SOUZA, A.L.; GARCIA, R. et al. Avaliação do vício de tempo longo de indicadores internos em ensaio de digestão com ruminantes. Arquivo Brasileiro de Medicina Veterinária e Zootecnia, v.59, p.182-188, 2007a.

DETMANN, E.; CECON, P.R.; PAULINO, M.F. et al. Variáveis ruminais avaliadas por meio de funções matemáticas contínuas. Pesquisa Agropecuária Brasileira, v.42, p.1651-1657, 2007b.

DIAS, M. Indicadores na coleta de digesta omasal e na cinética de trânsito do trato gastrintestinal de bovinos. 2009. 109f. Tese (Doutorado em Zootecnia) - Universidade Federal de Viçosa, Viçosa, MG.

GLINDEMANN, T.; TAS, B.M.; WANG, C. et al. Evaluation of titanium dioxide as an inert marker for estimating faecal excretion in grazing sheep. Animal Feed Science and Technology, v.152, p.186-197, 2009.

GOERING, H.K.; Van SOEST, P.J. Forage fiber analyses (apparatus, reagents, procedures, and some applications). Washington, DC: USDA, 1975. 20p. (Agricultural Handbook, 379).

HOPPER, J.T.; HOLLOWAY, J.W.; BUTTS JUNIOR, W.T. Animal variation in chromium sesquioxide excretion patterns of grazing cows. Journal of Animal Science, v.46, p.1098-1102, 1978.

HUHTANEN, P.; KAUSTELL, K.; JAAKKOLA, S. The use of internal markers to predict digestibility and duodenal flow of nutrients in cattle given six different diets. Animal Feed Science and Technology, v.48, p.211-227, 1994.

ÍTAVO, L.C.V.; VALADARES FILHO, S.C.; SILVA, F.F. et al. Comparação de indicadores e metodologia de coleta para estimativas de produção fecal e fluxo da digesta em bovinos Revista Brasileira de Zootecnia, v.31, p.1833-1839, 2002.

LANGLANDS, J.P.; CORBETT, J.L.; McDONALD, I. et al. Estimation of the faeces output of grazing animals from the concentration of chromium sexquioxide in a sample of faeces. I.Comparison of estimates from samples taken at fixed times of day with faeces outputs measured directly. British Journal of Nutrition, v.17, p.211-218, 1963.

LICITRA, G.; HERNANDEZ, T.M.; Van SOEST, P.J. Standardization of procedures for nitrogen fractionation of ruminant feeds. Animal Feed Science and Technology, v.57, p.347-358, 1996.

LINERUD, A.C.; DONKER, J.D. Factors affecting the excretion pattern of chromic oxide in feces of dairy cows on pasture. Journal of Dairy Science, v.44, p.1176-1177, 1961.

LITTELL, R.C.; FREUND, R.J.; SPECTOR, P.C. SAS system for linear models. Cary: SAS Institute, 1991. 329p.

MERTENS, D.R. Gravimetric determination of amylase-treated neutral detergent fiber in feeds with refluxing in beakers or crucibles: collaborative study. Journal of AOAC International, v.85, p.1217-1240, 2002.

MYERS, W.D.; LUDDEN, P.A.; NAYIGIHUGU, V. et al. Technical note: a procedure for preparation and quantitative analysis of samples for titanium dioxide. Journal of Animal Science, v.82, p.179-193, 2004.

MYERS, W.D.; LUDDEN, P.A.; NAYIGIHUGU, V. et al. Excretion patterns of titanium dioxide and chromic oxide in duodenal digesta and feces of ewes. Small Ruminant Research, v.63, p.135-141, 2006

OWENS, F.N.; HANSON, C.F. External and internal markers for appraising site and extent of digestion in ruminants. Journal of Dairy Science, v.75, p.2605-2617, 1992.

PRIGGE, E.C.; VARGA, G.A.; VICINI, J.L. et al. Comparison of ytterbium chloride and chromium sesquioxide as fecal indicators. Journal of Animal Science, v.53, p.1629-1633, 1981.

REGAZZI, A.J. Teste para verificar a igualdade de parâmetros e identidade de modelos de regressão não-linear. Ceres, v.50, p.9-26, 2003.

SAMPAIO, C.B.; DETMANN, E.; VALENTE, T.N.P. et al. Evaluation of fecal recovering and long term bias of internal and external markers in a digestion assay with cattle. Revista Brasileira de Zootecnia, v.40, p.174-182, 2011

SILVA, D.J.; QUEIROZ, A.C. Análise de alimentos: métodos químicos e biológicos. 3.ed. Viçosa, MG: Editora UFV, 2002. $235 p$.

SMITH, A.M.; REID, J.T. Use of chromic oxide as an indicator of fecal output for the purpose of determining the intake of pasture herbage by grazing cows. Journal of Dairy Science, n.38, v.5, p.515-524, 1955.

TITGEMEYER, E.C.; ARMENDARIZ, C.K.; BINDEL, D.J. Evaluation of titanium dioxide as a digestibility marker for cattle. Journal of Animal. Science, v.79, p.1059-1063, 2001.

VALENTE, T.N.P.; DETMANN, E.; VALADARES FILHO, S.C. et al. In situ estimation of indigestible compounds contents in cattle feed and feces using bags made from different textiles. Revista Brasileira de Zootecnia, v.40, n.3, p.666-675, 2011.

Van SOEST, P.J. Nutritional ecology of the ruminant. 2.ed. Ithaca: Cornell University Press, 1994. 476p.

WILLIAMS, C.H.; DAVID, D.J.; IISMAA, O. The determination of chromic oxide in faeces samples by atomic absorption spectrophotometry. Journal of Agricultural Science, v.59, p.381-385, 1962.

ZEOULA, L.M.; PRADO, I.N.; DIAN, P.H.M. et al. Recuperação fecal dos indicadores internos avaliados em ruminantes. Revista Brasileira de Zootecnia, v.31, p.1865-1874, 2002 . 